\title{
Реологические свойства нанокомпозитов на основе везувиана и сополимера этилена с гексеном
}

\section{Rheological properties of nanocomposites based on vesuvian and the copolymer of ethylene with hexene}

\section{И. В. Байрамова}

Институт Полимерных Материалов

Национальной АН Азербайджана

\author{
I. V. Bayramova \\ Institute of Polymer Materials \\ of the Azerbaijan National Academy of Sciences
}

Поступила в редакцию 19.09.2019, принята к печати 25.10.2019

\section{Абстракт}

Приводятся результаты исследования влияния температуры и напряжения сдвига на реологические свойства сополимера этилена с гексеном и его наполненных везувианом нанокомпозитов. Реологические измерения проводились в температурном диапазоне $190-250^{\circ} \mathrm{C}$. Изучена зависимость скорости сдвига от напряжения сдвига, эффективной вязкости расплава от скорости сдвига, зависимости вязкости расплава от температуры в аррениусовских координатах. Использование универсальной температурно-инвариантной характеристики вязкостных свойств нанокомпозитов позволяет путем экстраполяции в область высоких скоростей сдвига производить приближенные расчеты эффективной вязкости, близкую к условиям их переработки методами экструзии и литья под давлением.

\section{Abstract}

The results of studying the effect of temperature and shear stress on the rheological properties of a copolymer of ethylene with hexene and its vesuvian-filled nanocomposites are presented. Rheological measurements were carried out in the temperature range $190-250^{\circ} \mathrm{C}$. The dependence of shear rate on shear stress, effective melt viscosity on shear rate, and the dependence of melt viscosity on temperature in Arrhenius coordinates are studied. Using the universal temperature-invariant characteristic of the viscosity properties of nanocomposites allows by extrapolating to the region of high shear rates to make approximate calculations of the effective viscosity close to the conditions of their processing by methods of extrusion and injection molding.

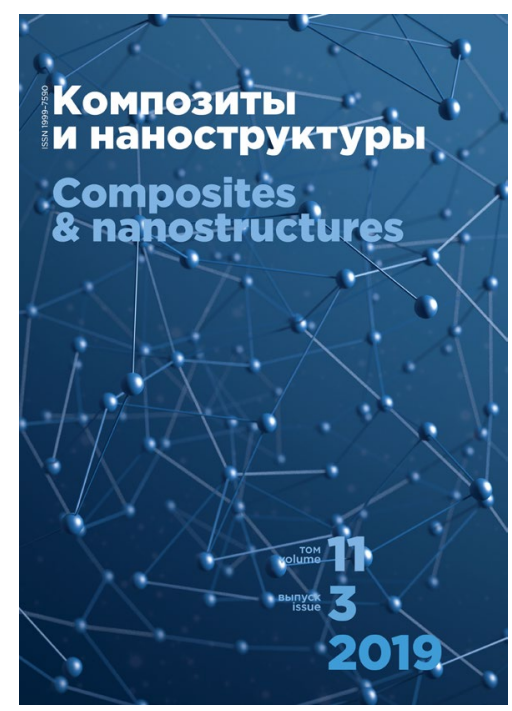

